\section{PRODORNE IN PREROŠKE MISLI 16. STOLETJA: ob petstoletnici Trubarjevega rojstva}

Nujen del kulturnega univerzuma niso samo vsem znane napovedi prihodnosti, ampak tudi »napovedi preteklosti« (Lotman 2006: 388).

Razprave za prvo in drugo številko revije Slavia Centralis so plod znanstvene konference Prodorne in preroške misli 16. stoletja: ob petstoletnici rojstva Primoža Trubarja (1508-1586), ki sta jo ob petstoletnici Trubarjevega rojstva organizirala Slavistično društvo Maribor ter Oddelek za slovanske jezike in književnosti Filozofske fakultete Univerze v Mariboru. Konferenca je potekala 4. in 5. junija 2008 na Univerzi v Mariboru, kjer so bila predstavljena aktualna znanstvenoraziskovalna spoznanja o duhovnozgodovinskih značilnostih 16. stoletja na slovenskem etničnem ozemlju, ki se je enakovredno vključevalo $\mathrm{v}$ tedanje evropske medkulturne tokove, spoznanja o književnih, jezikovnih in kulturnih prispevkih predvsem slovenskih protestantov in zlasti Primoža Trubarja. Njegove prodorne, inovativne, vsekakor pa z vidika sedanjega časa tudi preroške misli, ki jih je mnoge zapisal in uresničil v prvih slovenskih knjigah, številnih predgovorih in prevodih, cerkvenem redu, korespondenci in drugih svojih pomembnih delih, postavljajo Trubarja za začetnika slovenske književnosti, utemeljitelja slovenske protestantske misli ter slovenske narodnostne identifikacije $\mathrm{v}$ družbi in kulturi evropskih narodov.

Vodja konference sem bila doc. dr. Blanka Bošnjak, predsednica Slavističnega društva Maribor, organizacijski odbor pa so sestavljali: red. prof. dr. Miran Štuhec, predstojnik Oddelka za slovanske jezike in književnosti Filozofske fakultete Maribor; izred. prof. dr. Jožica Čeh, Oddelek za slovanske jezike in književnosti Filozofske fakultete Maribor; dr. Alenka Valh Lopert, tajnica Slavističnega društva Maribor; dr. Branislava Vičar, Slavistično društvo Maribor; dr. Natalija Ulčnik, Slavistično društvo Maribor; častni odbor so sestavljali: red. prof. dr. Ivan Rozman, rektor Univerze v Mariboru; red. prof. dr. Marko Jesenšek, dekan Filozofske fakultete Maribor; akad. red. prof. dr. Zinka Zorko, izredna članica SAZU v Ljubljani; red. prof. dr. Zvonko Kovač, Univerza v Zagrebu; dr. Janez Dular, vodja Sektorja za slovenski jezik pri Ministrstvu za kulturo RS; Mojca Kucler Dolinar, ministrica za visoko šolstvo, znanost in tehnologijo RS; Franc Kangler, župan Mestne občine Maribor; častni pokrovitelj konference je bil dr. Danilo Türk, predsednik Republike Slovenije. Na konferenci je nastopilo enaindvajset referentov $\mathrm{z}$ devetnajstimi referati (za simpozij sem uredila zbornik povzetkov), na moje povabilo pa jih je petnajst pripravilo tudi razprave za objavo v prvih dveh številkah nove slavistične revije Slavia Centralis.

Znanstvene razprave obeh številk revije Slavia Centralis izpostavljajo in izvirno vrednotijo delo slovenskih protestantskih piscev 16. stoletja izjemnih razsežnosti, s poudarkom na Trubarjevem neizbrisljivem pečatu in prvenstvu, pri čemer so prispevki tematsko razdeljeni na dve številki revije, ki pomenita smiselno vsebinsko zasnovo in možnost obvladovanja obsežnega območja snovi.

V prvi številki revije Slavia Centralis so tako zajeta naslednja literarnozgodovinska tematska vozlišča: Marko Štuhec razpravlja o reformacijskih gibanjih 
in idejah, ki so se razvile v verskem, družbenem, kulturnem in političnem okviru dolgega 16. stoletja. Dejan Kos obravnava učinke, ki jih je imela protestantska književnost na preoblikovanje stanovsko utemeljenih kulturnih polj v drugi polovici 16. stoletja. Alenka Jensterle Doležal analizira vprašanje vere in dvoma v dveh Trubarjevih delih: v delu Ena dolga Predguvor (1557) in Cerkovni ordningi (1564). Aleksander Bjelčevič podaja temeljit premislek o pomenu odpustkov, vsebini Lutrovih 95 tez in Trubarjevih omembah odpustkov. Barbara Pregelj na osnovi primerjave Primoža Trubarja in B. de Las Casasa ugotavlja številne vzporednice in pomembne razlike $\mathrm{v}$ življenju kakor tudi delu obeh avtorjev. Blanka Bošnjak izhaja iz teze, da se s pomočjo Trubarjevih izbranih analiziranih predgovorov in korespondence tedaj šele kaže konstituiranje raznolikosti diskurzov. Milena Mileva Blažić v Trubarjevih besedilih ugotavlja pogoste omembe otrok, ženske, družine, ljubezni v smislu novoveškega pojmovanja teh prvin. Ivana Latković in Zvonko Kovač pa razpravljata o širokem spektru pojavnih oblik zgodovinskega žanra, zlasti na primeru romana Draga Jančarja Galjot.

V drugi številki revije Slavia Centralis so zbrane razprave, ki sodijo na jezikoslovno področje: Marko Jesenšek razpravlja o Trubarjevem gmajn jeziku, ki je sopomenka za kranjski jezik. Prepoznaven je po splošni razumljivosti, hkrati pa gre za jezikovni kompromis, tj. skupni imenovalec osrednjeslovenskega knjižnega jezika. Irena Orel z različnih vidikov osvetli sistemsko in besedilno rabo protipomenskosti v Trubarjevem najbolj polemičnem besedilu, Katehizmu z dvejma izlagama (1575), ter $\mathrm{v}$ Pridigi od stare prave inu krive vere. Majda Merše zariše obseg rabe feminativov v slovenskem knjižnem jeziku 16. stoletja, pri čemer so predstavljene osnovne pomenske skupine feminativov ter načini njihove tvorbe. Andreja Legan Ravnikar analizira najbolj produktiven tvorbeni model pridevniških tvorjenk v 16. stoletju: izpeljavo s priponskim obrazilom -ski in različico -ški ter izpeljanke na -čki in -cki, ki se pripenjajo na enako besedotvorno podstavo. Irena Stramljič Breznik predstavlja besedotvorje predmetnopomenskih besed v prvi slovenski slovnici, ki jo je napisal Adam Bohorič, kar kaže na njegovo sposobnost kategoriziranja besedotvornih prvin. Matej Hriberšek piše o najzgodnejših virih slovenske klasične leksikografije, ki jih najdemo $v$ nekaterih ohranjenih ostankih iz srednjega veka in $\mathrm{v}$ delih slovenskih protestantskih piscev, vendar se slovenska leksikografija začne šele z delom Dictionarium quatuor linguarum, avtorja Hieronymusa Megiserja. Ob zaključku druge številke revije Slavia Centralis pa Marianna L. Beršadskaja razpravlja o Trubarjevem pomembnem delu in odmevih nanj $\mathrm{v}$ študijah ruskih slavistov.

Vse navedene izvirne znanstvene razprave v prvi in drugi številki revije Slavia Centralis s svojo pronicljivostjo utemeljujejo 16. stoletje kot prelomno v slovenskem kulturnem, verskem, jezikovnem, književnem in zgodovinskem smislu, hkrati pa se povezujejo z aktualnimi usmeritvami aktivnosti v letu 2008 pri nas, saj prinašajo tako vidike medkulturnosti na Slovenskem kakor tudi proslavitev Trubarjevega leta.

Blanka Bošnjak, Filozofska fakulteta v Mariboru 